\title{
Baylor backed over 'falsified data' claims
}

[SAN DIEGO] The US Office of Research Integrity (ORI) has concluded that a neuroscientist formerly at Baylor College of Medicine in Houston, Texas, intentionally falsified research data in five published articles and grant applications over a fiveyear period.

The case has taken on national significance because of the potential implications of a lawsuit which the researcher, Kimon Angelides, has filed against Baylor and those of its scientists and administrators who were originally involved in accusing him of misconduct (see Nature 383, 107; 1996 \& 384, 105; 1997).

The outcome of the suit is being closely watched both by the ORI and the Association of American Medical Colleges. The lawsuit, which Angelides filed in 1995 for wrongful termination, defamation and other alleged offences, has attracted this attention because of its potential to derail the process by which universities conduct scientific misconduct investigations.

According to an ORI report that was released last month, Angelides should be prohibited from receiving federal grants for five years because of "a lack of honesty and integrity". Angelides now works at the University of Durham in England, having been fired by Baylor in 1995 .

The ORI has ordered Angelides to notify five journals of the falsifications as a condition of receiving any future government grants. This is expected to trigger the retraction of the articles, which were published with co-authors from Yale University and the University of Michigan. No co-author was implicated by ORI in scientific misconduct.

Angelides has appealed against ORI's findings to the Departmental Appeals Board. This is setting up a three-person panel which will determine the federal government's final word on the case's administrative aspects.

In the appeal, Angelides' attorney wrote that the researcher "disputes each finding in which he is accused of falsification, fabrication and [of being] the sole perpetrator of scientific misconduct. To the extent that any errors were made in grant applications or scientific papers, such were not the result of any intent to deceive".

The attorney, James V. Pianelli, also asked the appeals board to delay its hearing until the conclusion of the lawsuit that Angelides has filed. The board's panel is to consider that request soon.

In his lawsuit, Angelides also contends that he should be able to sue Baylor in Texas state court. But Baylor believes it is immune from lawsuits such as that filed by Angelides, as it was following federal requirements to investigate misconduct allegations. The medical college and its allies also argue that such lawsuits in state court will have a chilling effect on professorial participation in scientific misconduct probes.

Baylor is appealing in federal court, with oral arguments set for the first week in June. A decision by the US Court of Appeals for the Fifth Circuit in New Orleans is expected to follow between 30 and 60 days later.

An attorney for Baylor, A. John Harper II, declines to comment on the substance of the ORI report. But he says that Baylor was "pleased that its findings in the Angelides matter have been upheld by ORI".

In parallel with the administrative and civil battles, Angelides remains under criminal scrutiny by the US Attorney's Office in Houston, which started an inquiry late last year into possible fraud charges for alleged false reporting on grants Angelides received from the National Institutes of Health (NIH).

A decision on whether criminal charges will be filed is not expected for some time because of an agreement said to have been made between federal prosecutors and Angelides. The agreement allows prosecutors to extend the statute of limitations for a criminal charge while Angelides is out of the country. It may allow prosecutors to observe the hearing of the appeals board, seeking information to support a criminal indictment.

All of these developments are being observed by officials at the University of Durham, who are declining to comment

until Angelides' appeals are complete.

At Baylor, Angelides' laboratory examined sodium channels in nerve cells in a search for medications or drug delivery routes. It was on $\mathrm{NIH}$ grant applications for such research from 1988 to 1992 that he is alleged by the ORI to have repeatedly falsified and/or fabricated results.

The five publications in question involved his sodium-channel exploration with laboratory-engineered antibodies, in particular an antibody created in his Baylor laboratory. These experiments produced figures and supporting text which were provided to the co-authors at Yale for use in their articles.

Yale officials say that they are waiting for official notification of the ORI findings. They are expected to retract the articles. The Michigan co-author is a former doctoral student at Baylor whose work is said by ORI to have been manipulated by Angelides.

After reviewing Baylor's report, ORI ruled that Angelides manipulated experimental results to produce desired figures for publication, mislabelled the type of nerve cells (central versus peripheral rat nerve tissue) used in experiments, or falsified the molecular weight of specimens.

The articles appeared in the Proceedings of the Royal Society of London, the Proceedings of the National Academy of Science, Glia, Brain Research and the Annals of the New York Academy of Science.

\section{Patent office replies to fears over ESTS}

[WASHINGTON] The head of the US Patent and Trademark Office has replied to criticism from the National Institutes of Health (NIH) about the office's decision to allow the patenting of short DNA sequences known as expressed sequence tags (ESTs) on the basis of their utility as molecular probes.

The NIH, led by its director, Harold Varmus, has predicted that this policy could quash research and product development because rights to an EST could encompass rights to the full-length gene to which it corresponds (see Nature 386, 312; 1997). But Bruce Lehman, the Commissioner of Patents and Trademarks, has responded that broad patent claims will not result from the policy.

"Patent claims, limited in scope to a specific novel and non-obvious EST, generally should not preclude the future patenting of the corresponding, later discovered, full-length gene of known function" or of therapeutic technologies arising from it, Lehman wrote.

Varmus had written to Lehman last month that he was "deeply concerned" about the EST announcement. Varmus pointed out that the NIH had decided in
1994 that "it was not in the best interest of the public health or science to pursue patents on partial or full gene sequences for which function and practical utility are unknown".

In his reply, Lehman also stressed that usefulness as a probe alone would not qualify an EST as patentable. "Mere allegation of the utility of an EST as a probe without further disclosure is not sufficient to meet the utility and enablement criteria," Lehman wrote.

Some claim that the response represents a retreat from the patent office's earlier policy announcement, because Lehman is acknowledging that an inventor must have some knowledge of the function or utility of the target gene for an EST used as a probe to satisfy legal requirements for patenting.

But Lawrence Goffney, deputy commissioner of patents, who made the initial announcement, denied that it was a retreat. He said that Lehman's letter reflected exactly what he had said earlier, namely that "any EST that can be used as a probe is patentable subject matter".

Meredith Wadman 